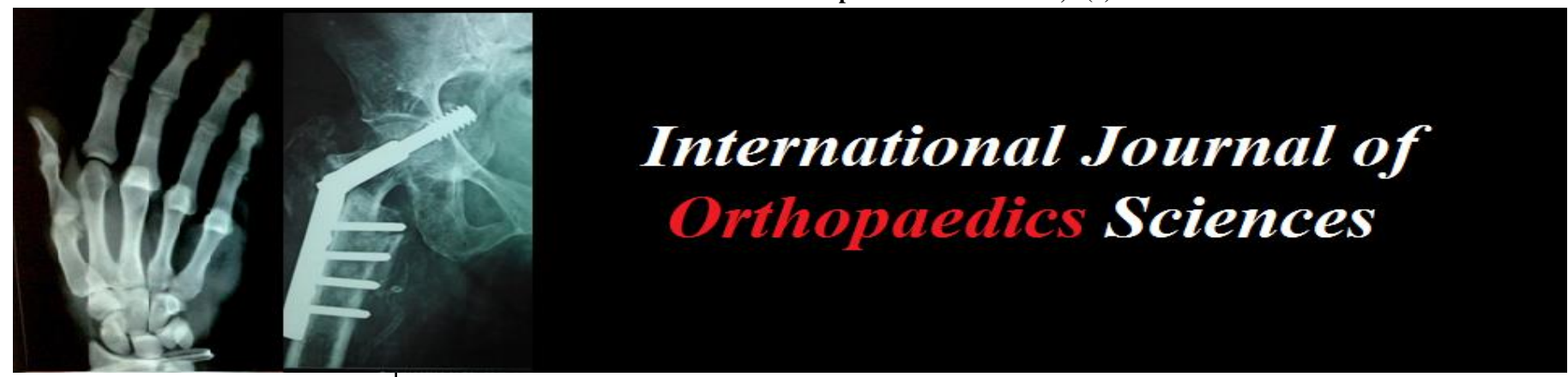

ISSN: $2395-1958$

IJOS 2018; 4(2): 561-565

(C) 2018 IJOS

www.orthopaper.com

Received: 24-02-2018

Accepted: 26-03-2018

Dr. Channareddy $H$

Associate Professor, Department of Orthopaedics, Basaveswara

Medical College Hospital and

Research Centre. Chitradurga.

Karnataka, India

Dr. Ambrish Sharma

Associate Professor, Department of Orthopaedics, Basaveswara

Medical College Hospital and

Research Centre. Chitradurga.

Karnataka, India
Correspondence

Dr. Ambrish Sharma

Associate Professor, Department

of Orthopaedics, Basaveswara

Medical College Hospital and

Research Centre. Chitradurga.

Karnataka, India

\section{Post-operative orthopaedic hyponatremia: Etiology and clinical approach}

\author{
Dr. Channareddy $\mathrm{H}$ and Dr. Ambrish Sharma
}

DOI: https://doi.org/10.22271/ortho.2018.v4.i2i.84

\section{Abstract}

Hyponatremia is common after orthopaedic surgeries. The prevalence of hyponatremia in the postoperative period is $25-40 \%$ in elderly patients. It can cause serious and potentially life threatening complications.

Identifying the cause (etiology) and providing appropriate treatment can mitigate the adverse effects of hyponatremia. Depending on the underlying cause, the treatment of hyponatremia can be markedly different. The aim of the study is to determine the cause of post-operative orthopaedic hyponatremia.

Methods: This is a prospective study of adults aged more than 65 years admitted with major lower limb fractures who developed post-operative hyponatremia. ECF volulme status was assessed by clinical examination and biochemical parameters.

Results: Thirty five patients developed post-operative hyponatremia. The most common cause of postoperative orthopaedic hyponatremia was hypovolemia $45.71 \%(n=16)$, followed by euvolemia (SIADH) in $25.71 \%(\mathrm{n}=9)$. Acute kidney injury, hypervolemia and medications each in 3 cases $(8.57 \%$ each), hypotonic fluids in one case. Etiology was multifactorial in $77.14 \%(\mathrm{n}=27)$.

Conclusions: Hypovolemia and euvolemia with SIADH are the two major causes of hyponatremia after orthopaedic surgery. The treatment requirements are exact opposites. Hypovolemia requires rehydration with IV fluids where as SIADH needs fluid (free water) restriction. Understanding the etiology of hyponatremia helps to treat hyponatremia with optimal use of IV fluids and avoids adverse outcomes.

Keywords: Orthopedic surgery, post-operative, hyponatremia, causes, diagnosis, practical approach

\section{Introduction}

Hyponatremia is a common electrolyte disorder and can lead to neurological complications. Post-operative period represents a significant risk for the development of hyponatremia. The prevalance of hyponatremia during post-operative period is upto 25 to $30 \%{ }^{[1,2]}$.

Hyponatremia is associated with multiple poor clinical outcomes including prolonged hospital stay, increased mortality and morbidity rates ${ }^{[3]}$.

The underlying cause of hyponatremia may be obvious if a precipitating cause is present such as vomiting, renal failure, blood loss after surgery or any other concurrent illness (risk factors). In most cases the differential diagnosis of hyponatremia is frequently complex and includes a wide range of pathophysiological settings with varying treatment.

Successful treatment of hyponatremia depends upon accurate diagnosis of the underlying etiology of hyponatremia. Identifying the cause of hyponatremia and appropriate treatment can diminish or mitigate the adverse effects of hyponatremia ${ }^{[4]}$.

The aim of the study is to identify the primary cause of hyponatremia using clinical and biochemical evaluation of patients with hyponatremia who have undergone surgery for major orthopaedic fractures.

\section{Methods}

This is a prospective study, conducted at tertiary care hospital and academic institution between 2015 and 2017. Patients more than 65 years old, who have developed post-operative hyponatremia following orthopaedic surgery for major bone fractures of lower limb were included in the study. Exclusion criteria - patients with head injury, patient who were treated conservatively without surgery were excluded. 
Patients demographic characteristics were noted. Laboratory data - serum sodium, potassium, chlorides, haemoglobin, hematocrit (HCT or PCV), blood urea, BUN, serum uric acid, serum creatinine, blood glucose levels, lipid profile (serum triglycerides), liver function tests (S. total proteins). Additional investigations were done where required - Thyroid function test (TSH).Serum electrolytes (sodium, potassium, chlorides) were measured in the first 2 days after surgery.

Assessment of etiology of hyponatremia:

First step is to assess whether the decreased sodium level is for real. Increased levels of serum triglycerides and serum total proteins in the blood cause spuriously low sodium levels. -psudohyponatremia. If these values are normal psudohyponatremia can be excluded.

Increased blood glucose levels also cause low sodium levels Translocational hyponatremia. If the blood glucose level is increased, real sodium level can be calculated using a corrective formula

Measured sodium $+0.024 \mathrm{x}$ (serum glucose -100$)$. Once psudohyponatremia and translocational hyponatremia is excluded what remains is true hyponatremia.

Hyponatremia is defined as serum sodium measurement of $<135 \mathrm{~m} \mathrm{~mol} / \mathrm{L}$. The critical next step is to determine the patients ECF (extra cellular fluid volume) status in the diagnosis of the underlying etiology of hyponatremia. Hyponatremia can be associated with hypovolemia, hypervolemia or euvolemia. ECF status can be assessed with history (vomiting, diarrhea, blood loss after trauma or sugery) fluid input output charts and physical examination. Parameters for clinical assessment of ECF volume status by physical examiantion are given in table No.1 ${ }^{[5]}$. Clinical examination findings of volume status (hypo/euvolemia/hypervolemia) can be corroborated by laboratory (Bio-chemical) parameters.

Table 1: Clinical evaluation of extra cellular volume (ECF) status:

\begin{tabular}{|c|c|c|}
\hline Hypovolemia (Dehydration) & Hypervolemia & Euvolemia (SIADH) \\
\hline $\begin{array}{ll}\text { - } & \text { Dry skin and mucus memberanes(dry } \\
& \text { tongou) } \\
\text { - } & \text { Decreased axillary sweating (dry axilla) } \\
\text { - } & \text { Decreasedskin turgor } \\
\text { - } & \text { Orthostatic hypotension } \\
\text { - } & \text { JVP } \downarrow \\
\text { - } & \mathrm{CVP} \downarrow \\
\text { - } & \text { Urine output } \downarrow \\
\text { - } & \text { Cognitive impairment } \\
\text { - } & \text { Weight loss }\end{array}$ & $\begin{array}{ll}\text { - } & \text { Peripheral edema in non- } \\
\text { surgical extremities or sacral } \\
\text { edema } \\
\text { - } & \text { Ascitis } \\
\text { - } & \text { JVP } \uparrow \\
\text { - } & \text { CVP } \uparrow \\
\text { - } & \text { signs of pulmonary edema } \\
\text { - } & \text { LVF }\end{array}$ & $\begin{array}{l}\text { - Diagnosed in the absence of any clinical } \\
\text { signs of hypovolemia or hypervolemia. } \\
\text { - } \quad \text { SIADH is a diagnosis of exclusion. } \\
\text { - } \quad \text { Edema-not seen clinically }\end{array}$ \\
\hline
\end{tabular}

Orthostatic Hypotension: > $20 \mathrm{~mm}$ decreased in BP and or $>20 \mathrm{bpm}$ increased in pulse rate (tachycardia) going from supine to standing position.

If the ECF volume status is not certain based on the physical examination, biochemical evaluation should be done to classify volume status ${ }^{[6]}$ (Table No.2).Still any doubt about volume status - Saline infusion test is done and response to therapeutic trial of IV normal saline infusion will reveal the volume status ${ }^{[7]}$.

Table 2: Heamodynamic and Biochemical measurements: to differentiate ECF volume status ${ }^{6}$

\begin{tabular}{|c|c|c|c|c|}
\hline & Normal values & Hypovolemia & Euvolemia (SIADH) & Hypervolemia (Volume overload) \\
\hline Haemo concentration & $38-50 \%(\mathrm{M})$ & $\uparrow 50-60 \%(\mathrm{M})$ & & \\
\hline Haematocrit (Hct/PCV) & $36-46 \%(\mathrm{~F})$ & $\uparrow 46-55 \%(\mathrm{~F})$ & & \\
\hline S. total proteins & $5.5-8 \mathrm{gm} / \mathrm{dl}$ & $\uparrow$ & & \\
\hline $\begin{array}{c}\text { Biochemical } \\
\text { Blood urea } \\
\text { Urea : creatinine ratio }\end{array}$ & $20-40 \mathrm{mg} \%$ & $\uparrow\left(\begin{array}{c}\uparrow \\
\uparrow(>\mathrm{mg} \%)\end{array}\right.$ & $\downarrow$ or normal & $\downarrow$ or normal \\
\hline $\begin{array}{c}\text { BUN } \\
\text { BUN: creatinine ratio }\end{array}$ & $10-20 \mathrm{mg} \%$ & $\begin{array}{c}\uparrow(>20) \\
\uparrow\end{array}$ & $\begin{array}{c}\downarrow(<10 \mathrm{mg} / \mathrm{dl}) \\
(<3.57 \mathrm{mmol} / \mathrm{L}) \\
\text { Normal } \\
\end{array}$ & $\downarrow$ \\
\hline S. Uric acid & $\begin{array}{c}\text { M-3.5-7.2 mg\% } \\
\text { F-2.6-6 mg/\% }\end{array}$ & $\begin{array}{c}\uparrow \text { or normal } \\
(>5 \mathrm{mg} \% \text { or } \\
\geq 0.3 \mathrm{mmol} / \mathrm{L}) \\
\end{array}$ & $\begin{array}{c}\downarrow \\
<4 \mathrm{mg} \% \\
(<0.24 \mathrm{mmol} / \mathrm{L}) \\
\end{array}$ & $\downarrow$ \\
\hline Urinary sodium excretion & & $<20 \mathrm{mmol} / \mathrm{L}$ & $>40 \mathrm{mmol} / \mathrm{L}$ & \\
\hline
\end{tabular}

Laboratory parameters to differentiate ECF volume status.

Hypervolemia can be easily detected by clinical examination, but it is difficult to differentiate euvolemia from subtle hypovolemic states ${ }^{[8]}$. Volume depletion can be diagnosed clinically from the history, physical examination and laboratory results. Patients without signs of volume depletion or volume expansion (subcutaneous edema, ascitis) should be considered to have euvolemia.

The underlying cause of hyponatremia is identified based on the findings from history, medications patient is taking, physical examination, laboratory investigation, fluid balance (input and output) charts and evaluation of ECF volume status.

\section{Results}

Thirty five patients who developed post-operative hyponatremia after major orthopeadic fractures between 2015 and 2017 were studied. Patient demographics and clinical characteristics are given in table No.3. 
Table 3: Demographics of study population

\begin{tabular}{|c|c|c|}
\hline & No. $(n=35)$ & Percentage \\
\hline \multicolumn{3}{|l|}{ Age (years) } \\
\hline Mean age & 71.94 years & \\
\hline Range & 65-89years & \\
\hline \multicolumn{3}{|l|}{ Gender } \\
\hline Female & 22 & $62.85 \%$ \\
\hline Male & 13 & $37.14 \%$ \\
\hline \multicolumn{3}{|l|}{$\begin{array}{c}\text { Fracture type } \\
\text { Proximal femer fracture }\end{array}$} \\
\hline Intra capsular & 6 & $17.14 \%$ \\
\hline Extra capsular & 24 & $68.57 \%$ \\
\hline Other fractures & 5 & $14.28 \%$ \\
\hline Supra condylar fracture femur & 3 & $8.57 \%$ \\
\hline Pelvis fracture & 1 & $2.85 \%$ \\
\hline Tibial plateau fracture & 1 & $2.85 \%$ \\
\hline \multicolumn{3}{|l|}{ Surgery } \\
\hline PFN & 18 & $51.42 \%$ \\
\hline DHS & 6 & $17.14 \%$ \\
\hline Hemi arthroplasty & 6 & $17.14 \%$ \\
\hline $\begin{array}{c}\text { Others } \\
\text { Comorbidities }\end{array}$ & 5 & $14.28 \%$ \\
\hline Hyper tension & 18 & $51.42 \%$ \\
\hline Diabetis Mellitus & 9 & $25.71 \%$ \\
\hline Chronic kidney disease & 5 & $14.28 \%$ \\
\hline Heart disease & 7 & $20.00 \%$ \\
\hline COPD & 5 & $14.28 \%$ \\
\hline Liver disease (Cirrhosis) & 3 & $8.57 \%$ \\
\hline $\begin{array}{l}\text { Medications } \\
\text { Diuretics }\end{array}$ & 7 & $20 \%$ \\
\hline $\begin{array}{l}\text { Anti depressents } \\
\text { (TCA, SSRI) }\end{array}$ & 6 & $17.14 \%$ \\
\hline $\begin{array}{c}\text { ACE inhibitors and } \\
\text { Angiotensin receptor blockers }\end{array}$ & 5 & $14.28 \%$ \\
\hline $\begin{array}{l}\text { Anti psychotic drugs } \\
\text { Haloperidol }\end{array}$ & $\begin{array}{l}2 \\
1\end{array}$ & $5.71 \%$ \\
\hline Clozpine & 1 & \\
\hline Anticonvulsants & & \\
\hline Carbamazepine & 1 & $2.85 \%$ \\
\hline
\end{tabular}

The mean serum sodium pre-operatively was $132.82 \mathrm{mmol} / \mathrm{l}$ (range 122 to 140 ) and post-operatively was mean 126.91 $\mathrm{mmol} / \mathrm{l}$ (range 113-134) with mean post-operative sodium fall of $5.91 \mathrm{mmol} / \mathrm{l}$.

Etiology of hyponatremia: Hypovolemia $45.71 \% \quad(n=16)$ followed by euvolemia (SIADH) $25.71 \%(n=9)$ were the most common causes of hyponatremia. Other causes include AKI, hypervolemia, medications each in 3 cases $(8.57 \%)$, use of hypotonic fluids (Ringer lactate, $5 \%$ dextrose) in one case. Etiology was multi factorial in $77.14 \%(n=27)$.

\section{Discussion}

Establishing the etiology of hyponatremia is notoriously challenging and requires accurate assessment of volume status. Hyponatremia can occur when there is either sodium loss or more commonly water retention. Total body water can increase as a result of increased intake or decreased renal clearance. This decreased excretion of water by the kidneys is due to the action of anti diuretic hormone (ADH or AVP) in the post-operative period.

Normally the prime regulator of $\mathrm{ADH}$ secretion is plasma osmolality but there is also osmolality independent stimuli (non-osmotic path way) - is dependent on barroreceptors in the major arterial system. With decrease in cardiac output or hypovolemia (blood loss after surgery) from any cause, nonosmotic pathway is stimulated and it overrides the osmotic pathway and results in release of AVP, activation of RAASRennin-Angiotensin-Aldosterone system and norepinephrine release, resulting in water reabsorption from distal renal tubule and collecting ducts of the kidney and water retention. The non-osmotic stimuli for ADH release includes the stress of surgery, post-operative pain, nausea, hypoxia, hypercarbia, pro-inflamatory cytokines (CRP, interleukins) ${ }^{[9]}$.

Hyponatremia develops as a consequence of increased ADH levels, which can occur in many conditions including trauma, surgery, blood loss, hypovolemia, inappropriate secretion of $\mathrm{ADH}$ (SIADH), post-operative states. This is exacerbated by the use of hypotonic fluids and medications (thiazide diuretics, SSRIS etc.) during post-operative period ${ }^{10}$. This peri operative stress response can last for 12 hours after minor surgery or 4 days after major surgery ${ }^{[11]}$.

The etiology of hyponatremia in elderly patients is predominantly multi factorial [12, 13]. Hypovolemia (dehydration) is a major cause of hyponatremia. This is the simplest and easily treatable cause of hyponatremia. Hypovolemic hyponatremia is accompanied by extra cellular fluid (ECF) volume deficit (depletion). Hypovolemia may due to blood loss from trauma or surgery, decreased oral intake, inadequate replacement of IV fluids and use of diuretics, GI loss - vomiting diarrhea etc. A variety of medications can cause hyponatremia by drug induced SIADH or circulating volume depletion ${ }^{[14]}$.

Euvolemic hyponatremia - there is a relative excess of water compared to sodium. Edema is not seen clinically because the excess water is mainly intra cellular.

SIADH is the most common cause of non-osmotic AVP release in euvolemic hyponatremia. SIADH is a diagnosis of exclusion ${ }^{[15]}$. SIADH is due to non-osmotic release of ADH. Post-operative state (surgical stimulus-stress, pain, anxiety, nausea, vomiting) coupled with use of hypotonic fluids and medications (narcotics, SSRIS) are prone to develop SIADH. SIADH must also be considered in patients with pulmonary infections - pneumonia, pulmonary abscess, active TB, asthama, CNS infection, neoplasm (Carcinoma).

Blood urea is highly sensitive to hypovolemia. Increased levels suggest hypovolemia, where as decreased levels indicates euvolemia or hypervolemia (increased ECF volume). In SIADH the ECF volume is expanded so blood urea levels are decreased ${ }^{[16]}$. Serum uric acid levels are also used in the differential diagnosis of hyponatremia. Serum uric acid levels are increased in hypovolemia and decreased in euvolemia (SIADH) ${ }^{[17]}$. Algorithm for diagnosis of etiology of hyponatremia is given in fig. 1 . 


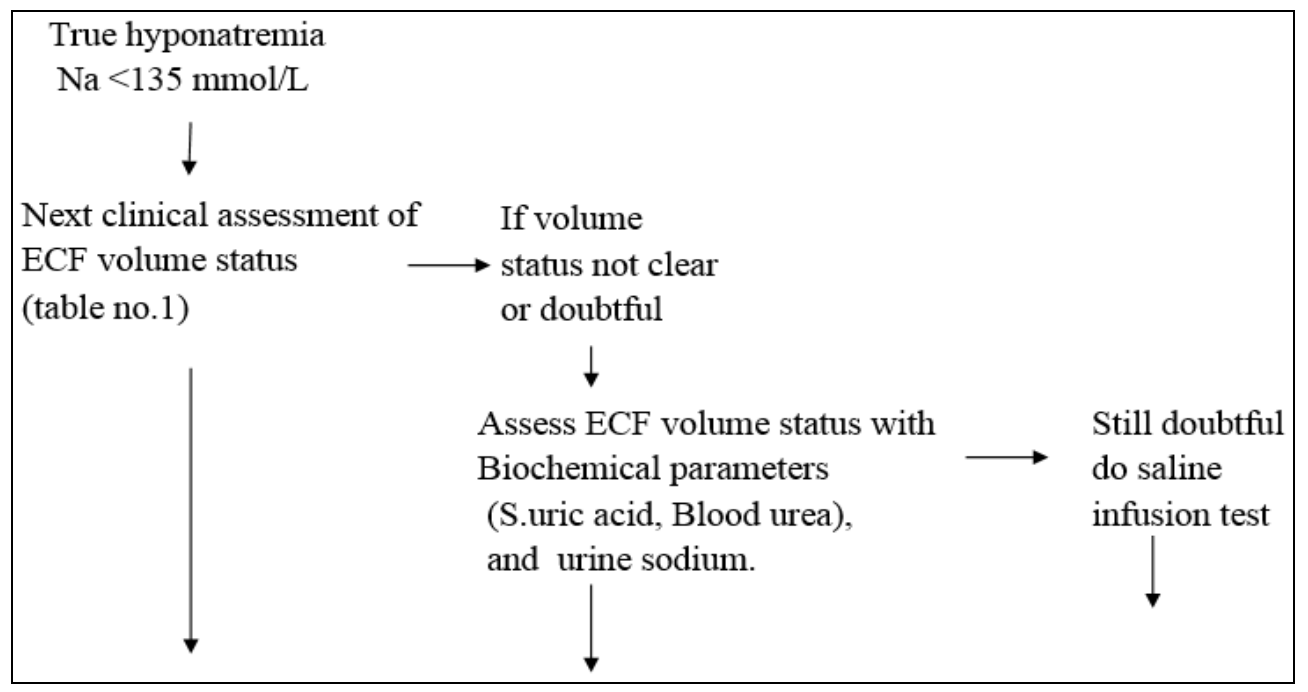

Fig 1: Algorithm for the diagnosis of etiology of hyponatremia

\begin{tabular}{|c|c|c|c|}
\hline & Hypovolemia & Euvolemia & Hypervolemia \\
\hline & Hypovolemic hyponatremia & Euvolemic hyponatremia & Hypervolemic hyponatremia \\
\hline \multicolumn{4}{|l|}{$\mathrm{K}^{+}$level } \\
\hline Normal & & $\begin{array}{ll}- & \text { SIADH - } \\
\text { - } & \text { Hypothyroidism-TSH } \\
\text { - } & \text { Cortisol deficiency - morning cortisol } \\
\end{array}$ & $\begin{array}{ll}- & \text { CCF } \\
- & \text { CRF/NS } \\
- & \text { Chronic liver disease } \\
- & \text { Fluid overload } \\
\end{array}$ \\
\hline Decreased & $\begin{array}{ll}\text { - } & \text { Vomiting } \\
\text { - } & \text { Diarrhea } \\
\text { - } & \text { Diuretic therapy } \\
\text { - } & \text { Paralytic ileus }\end{array}$ & Thiazide diuretics & \\
\hline Increased & $\begin{array}{ll}- & \text { CRF/AKI } \\
\text { - } & \text { Mineralocorticoid deficiency }\end{array}$ & - $\quad$ Adrenal insufficiency (AM cortisol) & \\
\hline Treatment & Fluidreplacement with normal saline & Fluid restriction and Vaptans(drugs) & Diuritics \\
\hline
\end{tabular}

NS - Nephrotic syndrome, CRF - chronic renal failure, AKI - Acute kidney injury.

The causes of orthopaedic hyponatremia in the post-operative period include hypovolemia-resulting from blood loss after surgery, inadequate fluid replacement, use of diuretics. Surgical process itself (Post-operative pain, nausiea, release of cytokines) produces non-osmotic stimulus for AVP release resulting in SIADH. Hypotonic fluid administration, acute kidney injury, medications (thiazide diuretics, SSRIS) and comorbidities (risk factors) can all cause hyponatremia in the post-operative state.

Most common cause of hyponatremia is hypovolemia (hypovolemic hyponatremia) as reported in the recent literature. Cumming $\mathrm{K}$ et al. reported hypovolemia as a cause of hyponatremia in $69 \%$ of patients and Henrikus et al reported in $33 \%$ of the patients in the post-operative period. In our study consistent with literature we found hypovolemia as a causative factor for hyponatremia in $45.71 \%(n=16)$. The second common cause is euvolemic hyponatremia (SIADH) as shown in table No.4. Hypervolemia is least common cause and is due to CCF in 2 patients and AKI in $8.57 \% \quad(n=3)$ patients.

Table 4: Etiology of hyponatremia

\begin{tabular}{|c|c|c|c|}
\hline Etiology & $\begin{array}{c}\text { Cummins K } \text { et al. } 2014 \\
(n=33 \text { with EPFF })\end{array}$ & $\begin{array}{c}\text { Henrikus et al. } 2016(\mathrm{n}=319, \text { joint } \\
\text { replacement })\end{array}$ & $\begin{array}{c}\text { Our study } \\
(\mathrm{n}=35, \text { major lower limb } \\
\text { fractures })\end{array}$ \\
\hline Multi factorial & $72.7 \%$ & & $27 / 35(77.14 \%)$ \\
\hline Hypovolemia & $69.7 \%(n=23)$ & $32.28 \%(n=103)$ & $45.71 \%(n=16)$ \\
\hline SIADH & $27.3 \%(n=9)$ & $31.03 \%(n=99)$ & $25.71 \%(n=9)$ \\
\hline Thiazide diuretics & $75.8 \%(n=25)$ & & $20 \%(n=7)$ \\
\hline CKD/AKI & $3.0 \%(\mathrm{n}=1)$ & $5.01 \%(n=16)$ & $8.57 \%(\mathrm{n}=3)$ \\
\hline $\begin{array}{l}\text { Hypervolemia } \\
\text { Heart failure } \\
\text { Liver cirrhosis } \\
\text { Fluid over load } \\
\end{array}$ & $\begin{array}{l}6.1 \%(n=2) \\
6.1 \%(n=2) \\
3.0 \%(n=1) \\
\end{array}$ & & $\begin{array}{c}\text { CCF } 2 \\
\text { CLD } 18.57 \%(n=3)\end{array}$ \\
\hline $\begin{array}{c}\text { Drugs } \\
\text { Amitryptaline } \\
\text { Sertraline } \\
\text { Mirtazapine } \\
\end{array}$ & $\begin{array}{c}3.0 \%(\mathrm{n}=1) \\
3.0 \%(\mathrm{n}=1) \\
15.2 \%(\mathrm{n}=5)\end{array}$ & $\begin{array}{c}\text { Overall } \\
5.64 \%(\mathrm{n}=18)\end{array}$ & $\begin{array}{c}\text { Overall } \\
8.57 \%(\mathrm{n}=3)\end{array}$ \\
\hline Hypotonic fluids & & $7.83 \%(n=25)$ & $2.85 \%(n=1)$ \\
\hline Undermined & & $14.10 \%(\mathrm{n}=45)$ & \\
\hline
\end{tabular}

$\mathrm{CCF}$ - congestive cardiac failure CLD - Chronic lung disease

$\mathrm{EPFF}$ - Elderly patients with fragility fractures. 
The diagnosis of etiology of hyponatremia is challenging because multiple mechanisms of hyponatremia may be occurring simultaneously in the post-operative state. ECF volume assessment is very important in the diagnosis of cause of hyponatremia and treatment of hyponatremia. The treatment of hypovolemia and euvolemia (SIADH) are very different. Hypovelemia requires rehydration with sodium containing fluids like $0.9 \%$ normal saline, whereas euvolemia requires fluid restriction. Hypervolemia is treated with diuretics. Multiple causes may be present in the same patient and may cause hyponatremia simultaneously.

Avoiding hypontonic and sodium poor solutions (Ringer lactate, $5 \%$ dextrose) in the post-operative period can prevent hyponatremia. Similarly avoid unnecessary use of medications associated with hyponatremia during peri operative period. Once hyponatremia develops, assess the mechanism causing hyponatremia. If the patient is hypovolemic (dehydration), resaucitate with $0.9 \%$ normal saline infusion. If the patient is euvolemic with SIADH, fluid restriction is necessary.

Understanding the etiology (mechanism) of hyponatremia in orthopaedic surgical patients and optimal use of (quantity and type of fluids) of intravenous fluids in the perioperative period avoids serious and potentially life threatening complications and improves clinical outcomes.

\section{References}

1. Hennrikus E, Ou G, Kinney B, Lehman E, Grunfeld R, Wieler J et al. Prevalence, Timing, Causes, and outcomes of hyponatremia in hospilized orthopaedic surgery patients. The Journal of Bone and Joint Surgery (American). 2015; 97:1824-1832.

2. Chung H, Kluge R, Schrier RW, Anderson RJ. Postoperative hyponatremia: A prospective study. Arch inter Med. 1986; 146:333-6.

3. Wald R, Jaber BL, Price LL, Upadhyay A, Madias N. Impact of Hospital associated hyponatremia on selected outcomes. Arch inter Med. 2010; 170:294-302

4. Waikar SS, Mount DB, Curhan GC. Mortality after hospitalization with mild, moderate and severe hyponatremia. Am J Med. 2009; 122(9):857-865.

5. Freda BJ, Davidson MB, Hall PM. Evaluation of hyponatremia: A little physiology goes a long way. Cleveland clinic journal of medicine. 2004; 71(8):639650.

6. Milionis HT, Liamis GL, Elisaf MS. The hyponatremic patient: a systematic approach to laboratory diagnosis. CMAJ. 2002; 166(8):1056-1061.

7. Assadi F. Hyponatremia: a problem solving approach to clinical cases. J Nephrol. 2012; 25(04):473-480.

8. Chung HM, Kluge R, Schrier RW, Anderson RJ. Clinical assessment of extracellular fluid volume in hyponatremia. American journal of medicine. 1987; 83:905-908.

9. Robertson GL. Antidiuretic hormone. Normal and disordered function. Endocrinol Metab Clin North Am. 2001; 30(3):671-94

10. Caramel C, Molina M, Tejedor A. Regulation of postoperative water excretion: a study on mechanisms. J Am Soc Nephrol. 2002; 13:654A.

11. Philbin DM, Emerson CW, Coggins CH, Moss JM, Slater E, Schneider RC. Renin catecholamine and vasopressin response to stress of anesthesia and surgery?. Anesthesiology. 1979; 51(3):S122.

12. Shapiro DS, Sonnenblick M, Galpherin I, Melkonyan L, Munter G. Severe hyponatremia in elderly hospitalized patients; prevalence, etiology and outcome. Inter Med J. 2010; 40(8):574-580.

13. Cumming K, Hoyle GE, Hutchison JD, Soiza RL. Prevalence, incidence and etiology of hyponatremia in elderly patients with fragility fractures. PLOS one. 2014; 9(2):e 88272.

14. Anderson RJ, Chung HM, Rudijer K, Schrier RW. A prospective analysis of its epidemiology and the pathogenetic role of vasopressin. Ann intern Med. 1985; 102:164-8).

15. Ellison DH Berl T. The syndrome of inappropriate antidiuresis. N Engl J Med 2007; 356(20):2064-2072.

16. Elisaf MS, Milionis HJ, Siamopoulos KC. Electrolyte abnormalities in elderly patients admitted to a general medical ward. Geriatr Nephrol Urol. 1991; 7:73-9.

17. Decaux G, Schlesser M, Coffernils M, prospert F, Namias B, Brimioulles et al. Uric acid anion gap and urea concentration in the diagnostic approach to hyponatremia. Clin Nephrol. 1994; 42(2):102-8. 